\title{
Validation of the Proposed Clinical Diagnostic Criteria of Enteric Fever
}

\author{
Neopane A, Panta S
}

Department of Medicine

Kathmandu Medical College

Kathmandu, Nepal

Corresponding Author

Arpana Neopane

Kathmandu Medical College

Kathmandu, Nepal

Email: arpana.neopane@gmail.com

Citation

Neopane A, Panta S. Validation of the Proposed Clinical Diagnostic Criteria of Enteric Fever. Kathmandu Univ Med J 2012;10(4):8-11.

\section{ABSTRACT \\ Background}

Enteric fever is very common infectious disease in developing countries like Nepal. Due to lack of resources diagnosis has to be clinical most of the time. Hence a proposal of clinical diagnostic criteria and validation of the same would be very useful.

\section{Objective}

To validate the proposed clinical diagnostic criterion including features characterized as major and minor criteria

\section{Methods}

This study was done in the department of medicine of Kathmandu Medical College Teaching hospital, from June 2009 to January 2012. A total of 114 patients presenting with fever were included in the study. After proposal of clinical diagnostic criteria for enteric fever, by a prior published study, all the fever patients were grouped according to criteria positive or negative. The most significant criteria were validated by calculating sensitivity and specificity along with positive and negative likelihood ratios with blood culture taken as gold standard.

\section{Results}

A total of 114 patients were enrolled. Total patients diagnosed as enteric was 47.3 $\%$. Clinical diagnostic criterion B which included three major (headache, fever and relative bradycardia) and three minor criteria (abdominal pain, vomiting, diarrhea, splenomegaly and chills) was highly significant $(p=<.0001)$ in diagnosing enteric fever and had a sensitivity of $72.2 \%$ ( $95 \% \mathrm{Cl} 58.1-83.1$ ) and specificity of $98.3 \%$ ( $95 \% \mathrm{Cl}$ 89.8-99-9). The positive likelihood ratio was 43.33 (95 \% Cl 6.16-304.77) and negative likelihood ratio as 0.28 (95\% Cl 0.18-0.43).

\section{Conclusion}

Clinical diagnostic criteria can be a very useful tool for diagnosis of enteric fever when culture facility is not available.

\section{KEYWORDS}

Enteric fever, diagnostic criteria, validation

\section{INTRODUCTION}

Enteric fever is a very common infectious disease in the developing countries. It is one of the major public health problems in Nepal and the incidence of typhoid fever is estimated to be $100 / 100,000$ cases. ${ }^{1}$ The paratyphoid fever, also included as enteric, is also increasing in incidence.$^{2} \mathrm{~A}$ lot of budget and resources are being spent to diagnose and treat enteric fever, but the incidence has not declined. Time and again the outbreaks of this disease lead to a lot of morbidity and mortality. ${ }^{3}$ Vaccine is available, but people requiring it are not vaccinated. 
Vaccinated due to inapproachability and lack of budget as well as firm government policy. Hence early diagnosis and implementation of treatment is very important. But again the diagnostic test are expensive and out of reach for the poor. The standards maintained by the diagnostic centers are also questionable leading very small yield of blood culture. Most of the time fever cases are treated at the locally available medical shops and clinics and hardly reach centers where proper investigations are done prior to initiation of therapy. This not only causes problem of misdiagnosis but poses risk of antibiotic resistance due to over the counter prescription of antibiotics so common in developed countries. Though much has been written about the clinical features of enteric fever it has always been discarded as nonspecific. ${ }^{3,4}$ A systemic analysis of the clinical features and its utilization has never been done. However clinical features of enteric fever can have diagnostic value. ${ }^{5}$ In this context if well validated criteria are applied for diagnosis as a health policy, expensive tests and use of health budget to procure expensive kits can be avoided when blood culture is not available. Initiation of proper therapy at the earliest can reduce a lot of morbidity and mortality associated with enteric fever. Hence a validated clinical criterion would be very useful. With this aim a preliminary study was done by Neopane et al, to determine the diagnostic value of various clinical features of enteric fever and diagnostic criteria were proposed. ${ }^{5}$ The criterion with the most significance was selected and this study was then designed to validate the said criterion.

\section{METHODS}

All patients presenting to the Internal Medicine department of Kathmandu Medical College Teaching Hospital with history of fever $>100$ degree $F$ for more than five days were included in the study conducted from June 2009 to January 2012. Patients with already confirmed diagnosis for fever at presentation were excluded. A total of 114 patients were enrolled during the period. After first contact with the patient, medical officers designated for the study took detailed history and filled the Performa which included all the relevant clinical features of enteric fever and also the clinical diagnostic criteria developed for enteric fever

\begin{tabular}{|ll|}
\hline Major criteria & Minor criteria \\
\hline Fever & Pain abdomen \\
\hline Headache & Splenomegaly \\
\hline Relative Bradycardia & Diarrhea \\
\hline & Chills \\
\hline & Vomiting \\
\hline
\end{tabular}

including major and minor criteria by Neopane et al. ${ }^{5}$

Criteria proposed were designated as A, B C D and E according to the presence of major and minor criteria. ${ }^{5}$
Details of the criteria according to presence of clinical features
A: Three Major clinical features
B: Three Major and three or more minor
C: Three Major and two minor
D: Two major and three minor

E: Two major and two or one minor criteria

Blood culture positive, taken as the gold standard diagnostic test, was sent for all the patients, blood specimens were incubated in liquid broth. They were sub-cultured on blood agar and McConkey agar.

If the duration of disease was more than seven days a Widal test was also sent. However diagnosis of enteric fever was not considered in cases where only Widal was positive. Bone marrow examination was not done as patients refused to give consent.

As the criteria B was statistically significant the results were grouped as criteria B positive, other criteria positive/ $B$ negative and none of the criteria positive. ${ }^{5}$ Regarding culture diagnosis grouping was done as follows

\section{Culture positive and Widal negative or not done}

\section{Culture negative and Widal positive}

3. Culture positive and Widal positive

4. Culture negative and Widal negative

Statistical analysis: Validation of the criteria B was done by calculating sensitivity; specificity; negative and positive likelihood ratio along with $95 \%$ confidence interval with online statistical calculator using $2 \times 2$ contingency table. ${ }^{6}$ The statistical significance of criteria $B$ and other criteria table was expressed calculating $p$ value by Fisher's exact test using online Graph pad software calculator. P value < .05 was taken as statistically significant.

\section{RESULTS}

A total of 114 patients were studied. The mean age of the study population was $29.4 \pm 14$.9. Male: Female ratio was 1.2:1. Mean duration of fever in the sample population was $12.5 \pm 8$. Total number of culture proven typhoid fever was $54(47.3 \%)$ and both culture and widal positive cases were $11(15.28 \%)$. Although Widal test with titre more than 160 was taken as significantly positive, the diagnosis was not made on the basis of this single widal test. However $25.4 \%$ of the study population had Widal test positive and culture negative. Regarding the diagnostic criteria the distribution is shown in table 1. Eighty five (74.6\%) patients with fever had clinical features included in one of the five diagnostic criteria and the criterion $B$ was the most significant $(p=<.0001)$ as compared with blood culture positivity. Table 2 shows the distribution of culture finding in various groups. Finally table 3 shows the validation. The 
Table 1. Distribution of different criteria.

\begin{tabular}{|c|c|c|c|}
\hline $\begin{array}{l}\text { Different } \\
\text { criteria }\end{array}$ & $\begin{array}{l}\text { Criteria positive } \\
n=(\% \text { of Total } \\
\text { cases) } N=85\end{array}$ & $\begin{array}{l}\text { Culture Positive } \\
\mathrm{n}=\text { (\% of culture } \\
\text { positive from } \\
\text { individual criteria } \\
\text { positive cases) }\end{array}$ & $\begin{array}{l}\text { Sig- } \\
\text { nificance } \\
\text { (Fisher's } \\
\text { exact) } p=\end{array}$ \\
\hline A & $\begin{array}{l}1 \\
(0.87) \mathrm{s}\end{array}$ & 0 & 1.0 \\
\hline B & $\begin{array}{l}40 \\
(35.08)\end{array}$ & 39 (97.5) & .00001 \\
\hline C & $\begin{array}{l}6 \\
(5.2)\end{array}$ & $2(33.3)$ & 0.6817 \\
\hline D & $\begin{array}{l}18 \\
(16.6)\end{array}$ & $6(33.3)$ & 0.2113 \\
\hline$E$ & 20 (17.5) & $7(35)$ & 0.3242 \\
\hline
\end{tabular}

Table 2. Comparison of criterion B with other criteria.

\begin{tabular}{lllll}
$\begin{array}{l}\text { Diag- } \\
\text { nosis of } \\
\text { typhoid }\end{array}$ & $\begin{array}{l}\text { Culture } \\
\text { positive and } \\
\text { Widal nega- } \\
\text { tive/Not done } \\
\mathrm{n}=(\%)\end{array}$ & $\begin{array}{l}\text { Culture } \\
\text { negative } \\
\text { and Widal } \\
\text { positive } \mathrm{n}= \\
(\%)\end{array}$ & $\begin{array}{l}\text { Widal posi- } \\
\text { tive } \\
\text { And culture } \\
\text { postive } \\
\mathrm{n}=(\%)\end{array}$ & $\begin{array}{l}\text { Widal } \\
\text { nega- } \\
\text { tive and } \\
\text { culture } \\
\text { negative } \\
\mathbf{N}=(\%)\end{array}$ \\
$\begin{array}{l}\text { Criteria B } \\
\text { positive }\end{array}$ & $36(31.6)$ & 0 & $3(2.63)$ & $(0.88)$ \\
$\begin{array}{l}\text { Other } \\
\text { criteria } \\
\text { positive }\end{array}$ & $7(6.14)$ & $29(25.4 \%)$ & $8(7.02)$ & $1(0.88)$ \\
\hline $\begin{array}{l}\text { Not fit- } \\
\text { ting any } \\
\text { criteria }\end{array}$ & 0 & 0 & & \\
\hline \begin{tabular}{l} 
Total \\
\hline
\end{tabular} & $43(37.7)$ & $29(25.4)$ & $11(9.64)$ & $31(27.19)$ \\
\hline
\end{tabular}

Table 3. Calculation and comparison of sensitivity and specificity of the clinical criteria.

\begin{tabular}{|c|c|c|c|}
\hline Diagnosis & Culture positive & Culture negative & $P=$ \\
\hline Criteria B positive & 39 & 1 & \multirow[t]{2}{*}{$<.001$} \\
\hline $\begin{array}{l}\text { Criteria B nega- } \\
\text { tive }\end{array}$ & 15 & 59 & \\
\hline $\begin{array}{l}\text { Sensitivity of } \\
\text { criteria } \\
B(95 \% \mathrm{Cl})\end{array}$ & $\begin{array}{l}72.2 \%(58.1- \\
83.1)\end{array}$ & $\begin{array}{l}\text { Specificity of } \\
\text { criteria } \\
\text { B }(95 \% \mathrm{Cl})\end{array}$ & $\begin{array}{l}98.3 \% \\
(89.8-99-9)\end{array}$ \\
\hline $\begin{array}{l}\text { Positive likeli- } \\
\text { hood ratio of B } \\
(95 \% \mathrm{Cl})\end{array}$ & $\begin{array}{l}43.33 \\
(6.16-304.77)\end{array}$ & $\begin{array}{l}\text { Negative likeli- } \\
\text { hood ratio of B } \\
(95 \% \mathrm{Cl})\end{array}$ & $\begin{array}{l}.28 \\
(.18-.43)\end{array}$ \\
\hline $\begin{array}{l}\text { Other criteria } \\
\text { positive }\end{array}$ & 15 & 30 & \multirow[t]{2}{*}{.0211} \\
\hline $\begin{array}{l}\text { Other criteria } \\
\text { negative }\end{array}$ & 39 & 30 & \\
\hline $\begin{array}{l}\text { Sensitivity } \\
\text { (CI) }\end{array}$ & $\begin{array}{l}27.77 \\
(16.8-41.8)\end{array}$ & $\begin{array}{l}\text { Specificity } \\
(\mathrm{Cl})\end{array}$ & $\begin{array}{l}50 \\
(36.9- \\
63.0)\end{array}$ \\
\hline
\end{tabular}

criterion B has the capacity to detect true positive cases of enteric fever with a probability of $97.5 \%$ (Cl 85-99.8), with a false positive rate of only $2.5 \%$. Similarly if the criterion is negative; the probability of enteric fever being absent is 79.72\% (Cl 68.4-87.8).

\section{DISCUSSION}

Clinical diagnosis of enteric fever without the aid of investigations sounds quite impossible when time and again researchers have said the clinical features are non specific. ${ }^{7}$ But if one argues that if clinicians can predict the probability of enteric by the symptoms and sign complex and ask for investigations to confirm, why can't a group of clinical features, confirmed to be diagnostic by repeated comparison with the gold standard investigation be used for diagnostic purpose. Our study started with this aim has successfully shown that the clinical diagnostic criteria can be useful in a poor country like ours for diagnosis of a very common infectious disease.

Haque et al showed that some of the clinical features can be strong markers of this condition. ${ }^{8}$ Similarly other studies by Kuvandik $\mathrm{C}$ et al and Khan et al showed the other studies predictive value of clinical features but included investigations too. They concluded that clinical and laboratory test together can help in diagnosis of enteric fever in absence of confirmatory tests. ${ }^{9,10}$ Ross et al also showed that clinical features are useful for diagnosis when culture is not available. However they included few basic investigations. ${ }^{11}$ Time and again various diagnostic tests have been proposed but none have been able to replace the blood culture test. ${ }^{12-16}$ Although the concept of pure clinical diagnosis and treatment may raise the question of issues like multidrug resistant typhoid. ${ }^{17}$ Hence simple clinical diagnosis and dependence on one or two anti-salmonella antibiotics like oral third generation cephalosporin or newer generation Quinolone may be used for treatment. This study is unique in that it avoids investigations and forms a purely clinical well validated diagnostic criterion and can be implemented in the primary health centers for treatment of enteric fever.

The criterion $B$ is statistically very significant $(p=<.0001)$ when compared with blood culture report. The sensitivity though only $72.2 \%$, the specificity is $98.3 \%$ (Cl: 89.8-99.9) which is very high. Moreover the results show positive likelihood ratio of $>10$ and negative likelihood ratio less than 0.4 . Thus clinical diagnostic criterion B can be considered to be well validated and can be used to diagnose enteric fever clinically.

\section{CONCLUSION}

Clinical diagnostic criteria can be very useful for diagnosis of enteric fever in resource restricted country like ours. 


\section{REFERENCES}

1. S Karki, K Kumar. Study on the possible use of Vi polysaccharide typhoid fever vaccine to control endemic typhoid fever in Nepal. Asian Pacific Journal of Tropical Disease 2011;1(1): 76-79.

2. Maskey AP, Basnyat B, Thwaites GE, Campbell JI, Farrar JJ, Zimmerman MD. Emerging trends in enteric fever in Nepal: 9124 cases confirmed by blood culture 1993-2003. Trans $R$ Soc Trop Med Hyg 2008;102(1):91-5.

3. Karkey A, Aryjal A, Basnyat B, Baker S. Kathmandu, Nepal: still an enteric fever capital of the world. J Infect Dev Ctries 2008; 2(6):461-5.

4. Lewis MD, Serichantalergs O, Pitarangsi C, Chuanak N, Mason CJ, Regmi LR et al. Typhoid fever: a massive, single-point source, multidrugresistant outbreak in Nepal. Clin Infect Dis 2005;40(4):554;61.

5. Neopane A, Poudel M, Pradhan B, Dhakal R, Karki DB. Enteric fever: diagnostic value of clinical features. Kathmandu Univ Med J (KUMJ) $2006 ; 4(3): 307-15$.

6. Newcombe, Robert G. "Two-Sided Confidence Intervals for the Single Proportion: Comparison of Seven Methods". Statistics in Medicine 1998; 17: 857-872.

7. Rahim Khan U, Razzak JA, Saleem AF, Ahmed A, Jalal S. Diagnosis of enteric fever in the emergency department: a retrospective study from Pakistan. Int J Emerg Med 2010 23;3(1):33-7.

8. Haq SA, Alam MN, Hossain SM, Ahmed T, Tahir M. Value of clinical features in the diagnosis of enteric fever. Bangladesh Med Res Counc Bull 1997;23(2):42-6.
9. Kuvandik C, Karaoglan I, Namiduru M, Baydar I. Predictive value of clinical and laboratory findings in the diagnosis of the enteric fever. New Microbiol 2009;32(1):25-30.

10. Khan M, Coovadia YM, Connoly C, Sturm AW. The early diagnosis of typhoid fever prior to the Widal test and bacteriological culture results. Acta Trop 1998;69(2):165-73

11. Ross IN, Abraham T. Predicting enteric fever without bacteriological culture results. Trans R Soc Trop Med Hyg 1987;81(3):374-7.

12. Parry CM , Wijedoru L, Arjyal A, Baker S. The utility of diagnostic tests for enteric fever in endemic locations. Expert Rev Anti Infect Ther 2011;9(6):711-25.

13. Ndububa DA, Erhabor GE, Akinola DO. Typhoid and paratyphoid fever: a retrospective study. Trop Gastroenterol 1992;13(2):56-63.

14. Wijedoru L, Arjyal A, Baker S. The utility of diagnostic tests for enteric fever. Expert Rev Anti Infect Ther 2011;9(6):711-25.

15. Wain J, Hosoglu S. The laboratory diagnosis of enteric fever. J Infect Dev Ctries 2008 ;2(6):421-5.

16. Olopoenia LA, King AL. Widal agglutination test - 100 years later: still plagued by controversy. Postgrad Med J 2000 ; 76(892):80-4

17. Onuigbo MA. Diagnosis of typhoid fever in Nigeria: misuse of the Widal test. Trans R Soc Trop Med Hyg 1990 Jan-Feb; 84(1):129-31. 